\title{
THE IMPACT OF SPECIAL ECONOMIC ZONES ON EXPORT BEHAVIOUR. EVIDENCE FROM POLISH FIRM-LEVEL DATA
}

\author{
Jarosław Michał Nazarczuk, Stanisław Umiński
}

\section{Introduction}

The establishment of Special Economic Zones (SEZ), and other types of privileged areas, is a common policy approach adopted by countries in order to attract domestic and foreign capital, increase exports or employment, increase trade openness or facilitate minor economic transitions within the country. By setting a preferential business climate, with lower taxes and tariffs made available in a restricted territory, governments promote investment inflow and encourage flourishing businesses to grow and cluster within zones, thus generating positive spill-over effects to the neighbouring areas.

Despite various policy types and approaches to establishing privileged areas, SEZs' success varies, being influenced by their location and size, set of incentives provided, quality and/or availability of resources (capital and labour), infrastructure, political, law and institutional environment, as well as stability of the government (Dobronogov \& Farole, 2012). In the wrong institutional framework, SEZs can lead to resource misallocation and rentseeking, whereas in a proper setting, these can lead to economic development (Moberg, 2015). Therefore, the efficacy of SEZ-led programmes is controversial (Chaudhuri \& Yabuuchi, 2010) and frequently questioned (Damborský, Wokoun, \& Krejčová, 2013), also as part of wider place-based policies (Neumark \& Simpson, 2015).

Although SEZs operate in more than 158 countries in total (Siroën \& Yücer, 2014) and significantly affect global trade flows (est. 851 bln USD, more than $40 \%$ of global exports) (FIAS, 2008), most of the empirical evidence on SEZs is focused on: (1) their role in the domestic economies, describing their contribution to the main country-level aggregates or (2) case studies of specific zones. The examples of selected works about SEZs' contribution in national exports include: Aggarwal (2004; 2005; 2012a; 2012b), Amirahmadi and Wu (1995), Bräutigam and Xiaoyang (2011), Farole (2011), Farole and Akinci (2011), FIAS (2008), Ge (1999), Kumar (1989), Kundra (2000), Mclntyre, Narula, and Trevino (1996), Milberg and Amengual (2008), Tantri (2011; 2012), Wong and Chu (1984), Zeng (2010; 2011; 2014). These include analysis conducted for Asian (China, India, Sri Lanka, Bangladesh, Honduras, Vietnam, Dominican Republic) and African countries (Egypt, Ghana, Kenya, Lesotho, Nigeria, Senegal, Tanzania).

The shortcomings of the research presented above are constituted by the lack of econometric methods being implemented, which forbids establishing a causal link between exports and SEZ operation. To our knowledge, the notable exceptions from this rule are the works of Johansson and Nilsson (1997), Wang (2013) and the working paper of Siroën and Yücer (2014). However, none of them investigates the firm-level consequences of operation in SEZs with regard to exports. They concentrate on international/national/regional implications for the zonal operation.

SEZs' operations are frequently criticised from a regional perspective. They can affect their vicinity by relocation of economic activity from outside of zones to their inside. It some of the cases, SEZs can also lead to an enclave effect, meaning the lack of cooperation with nearby local firms. Criticism is also done on micro-economic perspective (free-market disturbance). Notwithstanding the currently available body of literature, little is known about the primal objective of the SEZ operation, namely the promotion of exports (Siroën \& Yücer, 2014). The insufficient amount of empirical evidence is especially noticeable in the area of firm-level analysis, which is vital 
in the context of firm heterogeneity and new, new trade theory approaches. The operation in SEZs significantly affects firms' balance sheets by providing an extra competitive advantage, which is usually an income tax exemption with a set of other incentives offered to investors (such as lower tariffs, reduced local taxes, etc.). The article follows a relatively novel trend in export analyses, where firm heterogeneity is a crucial factor in terms of explaining firms' propensity to export and the export intensity thereof.

The paper fills in the existing gap in the literature by presenting the impact and role of SEZs in firm's activity and investigates the potential efficacy of the SEZ-led programme. Given the scarcity of firm-level empirical evidence on SEZs operation with reference to foreign trade, the paper's contribution is threefold: (1) to the knowledge of the authors, it is the first attempt to investigate firm-level consequences of SEZs operation with regard to export performance, (2) proposing the method of firm-level SEZs evaluation that enables the elimination of the endogeneity bias that can be applied to other datasets, (3) investigation of potential efficacy of the SEZs programme regarding firm-level export promotion. With the access to firm-level data the presented analysis sheds a new light, closer in its nature to recent developments in trade theories, on the issue of SEZs functioning.

Given the extra benefits stemming from the operation of SEZs (e.g. tax reliefs), the effects of SEZs on firm's export behaviour (export propensity) and export intensity are investigated, with the use of a unique dataset combining firm-level information for 155 firms in SEZs and 155 non-SEZ firms (matched sample), derived from a couple of sources, due to the insufficient amount of information provided by the Polish public statistics. Since the uneven nature of the collected data (discrete/continuous), different types of estimators are used. A possible endogeneity problem in the SEZ variable is addressed by utilising a kernel-based, propensity score matching, the differencein-difference estimator and calculating the average treatment effect on the treated (ATT). The calculation of the ATT values enables the examination of the sources of the differences in export probability/intensity between firms, namely (1) operation in SEZs or (2) firms' heterogeneous characteristics. Additional intention is put to the internationalisation pattern through exports. Being inspired by Mayer and Ottaviano (2007), the authors focus on the extensive vs. intensive margins of exports, as well as on the intensity of exports. This kind of an approach has enabled the demonstration whether the functioning of the SEZs, inflow of FDI and other factors increases the number of firms involved in exports, or rather increases the export involvement of already active firms.

The obtained results provide the evidence for a positive role of SEZs on firm-level export performance. The SEZs affect firms' export performance on the basis of intensive margin, mostly via productivity increases and foreign capital involvement. The semi-observational experiment confirmed the positive role of SEZs on export propensity, export intensity, scale of exports, log of exports, but only in the case of export propensity the result was robust to different sensitivity testes performed.

The findings enabled to join into the deliberations on the essence of the SEZs' existence and its severe firm-level consequences for the economic entities located in the SEZs. The implications stemming from the research may be helpful in: recognising the real effects of SEZs on firm-level export behaviour, introducing amendments in the SEZs programme carried on in Poland or the actions directed towards prolonging the operation thereof. The results, due to similarities among Eastern European countries and their economic policy programmes, can share similar implications for the SEZs-led policies carried on. However, each of the case should be studied carefully, knowing the potential differences, together with unequal sectoral effects.

\section{The Impact of SEZs on Export Behaviour - Review of Main Theories, Concepts and Empirical Research}

Upon initial review, the relation between the functioning of SEZs and export performance seems obvious. SEZs are expected to positively influence exports considering that they attract many foreign owned entities (FOEs) and that the underlying motive for establishing SEZs is to improve competitiveness, which is predominantly identified with the upswing of the exporting activity. Thus, endogeneity is the issue that shall be tackled with special attention 
while making an econometric inquiry. However if the relation between the functioning of SEZs and the performance of exports is thoroughly investigated, the following aspects shall be taken into account:

- not all SEZs succeeded to attract FOEs,

- even if this was not the case, not all FOEs are oriented towards exporting to a great extent,

- depending on the motives that drive the activity of FOEs in Poland, some of them merely entail seeking for resources, including cheap labour force, and for them Poland constitutes a target market,

- starting with year 2008, the domestic market has represented the most promising sales target for many firms, especially when one takes into account the fact that for most of them the domestic market dominates in terms of total sales (intensity of exports is low).

Bearing in mind the aforementioned arguments, it would be interesting to apply the methodology based on the heterogeneity concept to the research focused on the SEZ activity in Poland, which practically means to make use of firm-level data. Such an approach would make it possible to verify the so-called conventional wisdom on the role played by SEZs in the economy of Poland. More important would be the cognitive value for economic and especially regional policy, as regards the consequences of business activity in SEZs. These consequences do not relate to the exporting activity alone. They have to be understood in a broader sense, also with reference to the innovation activity. Although both these aspects are closely interrelated in light of the heterogeneity concept and empirical research, increased innovativeness of Poland's economy constitutes one of the top priorities of the economic policy. Poland faces the challenge of a shift towards an innovationdriven economy, which is now the crucial target of the economic policy.

The following strands of theoretical literature seem to be relevant in order to look into the nexus between SEZs and exports:

1. Competition policy theory, as SEZs can be interpreted de facto as public aid provided to enterprises doing business in privileged areas.

2. FDI theory, as many of the firms active in SEZs are FOEs, and the most important exporters are FOEs. This observation applies not only to businesses active in SEZs but in Poland in general.

3. Regional development and regional policy theory, considering that at least in the years when the SEZs were established they were declared, to be an instrument of regional policy.

4. New economic geography, considering that SEZs' operations can be assessed from the perspective of reallocation and agglomeration of the economic activity.

5. Economic development theory - SEZs are also intended to upgrade innovativeness. This aspect of their activity shall be perceived from the perspective of the growth theory with special focus on the deep determinants of economic growth that are important for the country facing the challenge of having to shift from low labour costs (or broadly speaking, from a resources-driven growth) to an innovation-driven growth.

6. Firms' heterogeneity concept by Melitz, in which the focus is placed on a firm level analysis that differentiates exporters from non-exporters, and investigates an array of other factors that are crucial for enterprises in order to become exporters.

Within the six aforementioned theoretical frameworks, it is possible to have a series of literature studies. Nevertheless, a particular amount of time will be required in order to reveal most of them. It is not possible however to unequivocally judge which studies may be deemed as most relevant. From the point of view of our research, two concepts may be regarded as such: (1) Melitz's heterogeneity concept and (2) the FDI theory.

Within the current body of research on international trade, heterogeneity is a crucial concept widely used in empirics, considering that individual firm data has become increasingly available. Gopinath, Helpman, and Rogoff (2014) leave no doubt as to what the most crucial theories or paradigms might be when it comes to the analysis of the concurrent international trade. The issues at stake are: trade costs, corporate behaviour, innovation and productivity. Thus, the international trade (occurring between and among countries) questions are analysed from a microeconomic perspective. Whereas Antras, Pol, and Yeaple (2014) concentrate on the influence of multinational firms on the 
structure of international trade, with a focus on firms' heterogeneity, as well as on the proximityconcentration hypothesis.

The approach, undertaken in the paper to the SEZs exports analysis is in line with the above-mentioned attitude. Heterogeneity is the underlying concept, being the theoretical foundation of the research, which was designed to make use of firm-level data. FOEs are the key driver of structural changes that occur in the economy of Poland. About 60 percent of Poland's exports is attributed to FOEs. Their export propensity is much higher, compared to domestic enterprises. They are performing the functions described by Forsgren (2008) as: dominators, coordinators, knowledge creators, designers, networkers and political "animals". Regardless of whether one is of the opinion that FOEs are rather a beast or a beauty (Forsgren, 2008), their strong influence on the economy of Poland cannot be questioned.

When it comes to the review of the empirical literature, finding solid evidence of the influence of SEZs on exports is not an easy task, the reason being primarily constituted by poor access to firm-level data. A large portion of the conducted research is conditional and based on the local economic environment, does not employ econometric models and ignores the endogeneity bias.

Lonarkar (2014) analysed the export performance of SEZs in India, a country in which SEZs are predominantly viewed as an instrument of export promotion. He finds significant differences between the particular zones as regards their export performance. In many cases, the SEZs did not reach the targeted levels of exports. His conclusion is that the implementation of SEZs as an instrument of export promotion shall be treated with caution. Furthermore, in a research study conducted by Tantri (2011), a zone trade performance index is used for seven privileged areas in India, leading to the identification of serious differences among SEZs. The author points out that "these enclaves are equally susceptible to changing fortunes in the world economy" (Tantri, 2011, p. 280), which means that the sectoral and geographical structure of trade links is important in the case of each and every zone. In another publication devoted to the export performance of privileged areas in India, Tantri (2012, p. 37) concludes that an important task is to identify the comparative advantages of each region and on these grounds to formulate export promotion strategies.

Moberg (2015) presents a rather critical view on the functioning of SEZs. She uses the framework of political economy as well as a rent-seeking concept to depict the influence of SEZs on the economy, incl. exporting activity. She points out that the requirements imposed on SEZs resemble state-planned industrial clusters, rather than liberalised free zones. Reference is also made to harmful export subsidies.

Pradhan and Zohair (2014) are examining export performance and the determinants thereof for two Indian regions. They found that export is led by firms that are relatively newly established, large, perform $R \& D$ and are owned by foreign investors.

Siroën and Yücer (2014), using a gravity model for countries, come to the conclusion that privileged areas, such as free trade zones, undoubtedly play an important role in the process of consolidating the global value chains. They conclude that such zones contribute to the development of international trade by easing the negative impact of protection, as the enterprises situated in these zones are importers of components and raw materials.

Johansson and Nilsson (1997), with the use of a similar econometric approach, tested the effects of SEZs with respect to national exports in 11 developing countries. The effect of SEZs varied, being influenced by the national trade strategy adopted. The more outward-oriented countries had a higher probability of receiving a positive impact on exports from the operation of SEZs.

Wang (2013), with reference to the endogeneity problem, has found a causal link between the SEZs and FDIs operating in Chinese municipalities, but did not consider exports. SEZs have facilitated the FDI inflow, have neither crowded-in nor crowded-out investments, generated agglomeration economies, as well as increased the workers' wages, factor prices and TFP. The older zones had a greater effect on local economies than newer ones, while the higher number of SEZs within a particular municipality had a stronger effect on the agglomeration economies, TFPgrowth and factor prices compared to the local areas having one economic zone.

Following a review of both theoretical and empirical lines of research, a hypothesis $\mathbf{H} 1$ was 
formulated: functioning in SEZs positively influences the exporting activity of firms. The verification of the hypothesis was carried out using model estimations, with dependent variables, related to the exporter status, volume of exports, exports intensity and log of exports. The research question seeks to investigate whether the establishment of SEZs can be regarded as an effective way of promoting exports. More specifically, an inquiry is made into the pattern of internationalisation through exports, looking into how the independent variables impact on the extensive and intensive margins of exports as well as into export intensity.

\section{Background, Dataset and Estimation Strategy}

In the following paragraph some stylized facts on the establishment and operation of SEZs in Poland are briefly discussed to provide better understanding of their role in the national economy and firms' standings. In the part 2.2 the sources of data, methods of its compilation and descriptive statistics are provided. Lastly, the foundations of the semi-observational experiment are delivered, coupled with the set of robustness tests.

\subsection{Background}

Poland introduced the SEZs programme in 1995 , as a result of the place-based policy (originating from the first Irish Free Trade Zone in Shannon) directed towards less developed regions during its preliminary years of transition. Initially, SEZs were only located within areas encountering serious economic problems, experiencing high unemployment or having an uncompetitive monoculture of industry branches with a need of rapid transformation. Given the significant east-west divide in regional economic prosperity (as a result of historical legacy and of over a century of annexation that divided the country into 3 different nations, and was further embraced by the former central planned economy), their role was to strengthen the economies of the less competitive eastern regions, as well as to enhance: foreign/ domestic capital inflow, exports, employment, technological and technical advancement, competitiveness of manufactured products and to restructure the remaining production assets.

As SEZs were operating in consecutive years, the location factors were gradually becoming less significant, as the criteria for establishing new subzones for the SEZs were more beneficial to the investor decisions (willing to employ a high number of workers or invest a relatively high capital expenditure) seeking the right plot for operation. The most recent picture of the location of SEZs is primarily the result of objective location factors than of a regional policy tool, directed towards diminishing the differences in regional wealth. Most companies within SEZs are located in the south-western part of the country, with a relative ease of access to foreign markets, in areas being strongly industrialised, and in many cases having a relatively high level of GDP per capita and superior infrastructure endowment.

14 SEZs operate in Poland, with several hundreds of subzones, offering different sizes and quality of plots. In 2015, the privileged areas in Poland covered 20 thousand hectares, out of which 59.5 per cent was occupied by firms operating in SEZs, having a total of 2,177 valid permits. The zonal activity amounted for 312 th. workers employed and 111.7 mld PLN (ca. 27.02 million Euros) of cumulated (from the start of the SEZs operation) capital investments. About half of the companies located within the zones are FOEs, while the rest are domestic entities, which differ from the rest of the companies in Poland in terms of size, scale of investments and export propensity. Between 2010 and 2014, the SEZs have attracted about 33 percent of the total FDI inflows to Poland.

The SEZs permit is granted for the firms that have filed a proposal to SEZ, in which they declare inter alia the type of investment, branch of activity (consistent with the list of economic activities permitted in SEZs), minimum of 100 th. EUR of new investments, choose a location, and win the tender organised by the SEZ for the SEZ plant. The bilateral agreement between the firm and the Ministry of the Development regulates the circumstances under which the tax privilege is granted, i.e. the minimum duration of the firm activity within SEZs, the level of capital investments or employment. In some cases of the firms (i.e. size of investment, innovative activity) the permit is given to the site indicated by the firm, on which a permit for zonal operation can be granted.

Firms having a valid permit to operation in SEZs can obtain a package of tax incentives and other privileges offered to investors: 
(i) income tax exemption - PIT or CIT (vs. normal 19 percent corporate tax or $18 / 32$ percent income tax), (ii) a fully prepared site, (iii) assistance in dealing the formalities with investment. Since 2004, the tax exemption is granted on a regional aid scheme, therefore despite the same conditions of firm operation, the scale of aid is an outcome determined by the regional map, the size of a firm and by capital investments - see Ambroziak (2015) for details. However, prior to 2014, the regional differences in the allotted public aid due to regional characteristics were negligible. In many cases, local authorities offer extra tax exemptions for several years under their authority (usually a property tax). However datasets on the scale or role thereof are unavailable.

\subsection{Dataset}

The data used in the study comprise unique information obtained from three major sources: The Ministry of Development, InfoCredit and survey research. The idea behind the hybrid type of data sources was to overcome difficulties and discontinuities in important data on firm-level activity in public statistics in Poland (employment and financial standings for small and medium-sized firms). Therefore, the proper organisation of the research was crucial in order to obtain the essential missing information.

The Ministry of Development supervises the issuance of operation permits in SEZs and provides a valid list of firms for which privileges were granted. Due to the lack of data on the share of economic activity carried out within the zones (for firms operating simultaneously within and outside SEZs) the obtained list was verified in order to check whether the firms having the permits had already started their operation in SEZs (on the basis of their capital investments and employment within the zones).

The list of firms was then used in order to organise the survey research and data purchase from InfoCredit, which is Poland's exclusive data supplier for the Amadeus database. Upon obtaining the information on firms' size, branch of economic activity (2-digit NACE), presence of foreign capital, employment, incomes from the production sold, capital assets, foreign trade for all of the firms operating in SEZs in Poland (1,273 in 2014), a sample of 155 firms was drawn according to the structure of the whole population of the firms within the zones (in terms of their size, branch, presence of foreign capital and export activity). The firms were subsequently inquired with the survey questionnaire.

The control group of 155 firms, operating outside the zones, was drawn out from a large InfoCredit database in a similar manner, namely according to the structure of the treatment group, and in respect to their size, branch and presence of foreign capital. In the end, all sources of data were merged in order to achieve a consistent dataset.

Tab. 1 presents the detailed information on the dataset, as well as the descriptive statistics of all the variables used in this study in two time periods - for years 2004 and 2014 altogether. One can notice infrequent missing data for a series of firms regarding theirs logs of exports and quite frequent missing data regarding labour productivity, calculated as the net sales from the production sold divided by the number of workers. Other missing data have more serious implications for the number of cases in the dataset. Therefore, the use of information on remuneration costs per employees, limits our population even more significantly.

Due to the protection of statistical secrecy for the firm-level data in Poland, the value of exports is only available as an ordinal variable with nine strata, identifying the scale of exports in EUR, plus information whether a firm has or has not exported any goods. The volume of exports is coded as follows (in EUR): (0) not exporter, (1) < 231 th. EUR, (2) (231 th. EUR; 924 th. EUR], (3) (924 th. EUR; 2,31M EUR], (4) (2.31M EUR; 6.93M EUR], (5) (6.93M EUR; 11.55M EUR], (6) (11.55M EUR; 17.33M EUR], (7) (17.33M EUR; 23.1M EUR], (8) > 23.1M EUR.

The various methods of data acquisition have enabled the obtainment of the missing data on the scale of exports from the survey research. The variable lexports is the log of exports calculated as the export intensity (the share of exports in net incomes from the production sold) multiplied by the net incomes from the production sold (obtained from the InfoCredit database). It was the best proxy of exports at firm-level one can obtain in Polish terms. To our knowledge, it was the first application of such an approach.

\subsection{Estimation Strategy}

In order to carefully analyse the complex nature of the firm-level factors determining the export 


\section{Tab. 1: Descriptive statistics of the variables used}

\begin{tabular}{l|l|c|c|c|c|c}
\multicolumn{1}{c|}{ Variables } & \multicolumn{1}{c|}{ Description } & N & mean & sd & min & max \\
\hline foe & Presence of foreign capital & 620 & 0.239 & 0.427 & 0 & 1 \\
\hline ex & Exports (scale) & 620 & 1.971 & 2.415 & 0 & 8 \\
\hline $\mathrm{im}$ & Imports (scale) & 620 & 1.948 & 2.361 & 0 & 8 \\
\hline exp & Exporter status & 620 & 0.565 & 0.496 & 0 & 1 \\
\hline imp & Importer status & 620 & 0.573 & 0.495 & 0 & 1 \\
\hline Ilab_prod & Log labour productivity & 480 & 5.572 & 1.578 & -2.845 & 9.959 \\
\hline Irenum_emp & Log remuneration costs per employee & 311 & 3.548 & 0.732 & -1.253 & 6.161 \\
\hline Irenum & Log remuneration costs & 406 & 7.306 & 1.730 & 0.693 & 12.070 \\
\hline ex_in & Export intensity & 620 & 25.740 & 29.530 & 0 & 100 \\
\hline lemp & Log employment & 620 & 4.036 & 1.488 & 0 & 7.696 \\
\hline lexports & Log exports & 521 & 6.195 & 9.899 & -6.908 & 19.200 \\
\hline lex_in & Log export intensity & 620 & -0.177 & 4.915 & -6.908 & 4.605 \\
\hline lage & Log firms' age & 620 & 2.693 & 0.538 & 1.386 & 4.771 \\
\hline sez & Operation in SEZs & 620 & 0.427 & 0.495 & 0 & 1 \\
\hline limports & Log imports & 521 & 4.932 & 9.992 & -6.908 & 18.870 \\
\hline im_in & Import intensity & 620 & 17.860 & 24.230 & 0 & 100 \\
\hline lim_in & Log import intensity & 620 & -0.995 & 4.914 & -6.908 & 4.605 \\
\hline
\end{tabular}

Source: own compilation

activity, the export intensity and the volume of exports with a particular reference to the impact of the SEZs operation, different econometric models were estimated to achieve consistent results. The general form of the estimated models was the following:

$$
E_{i}=\beta_{0}+\beta_{1} S E Z+\beta_{i} X_{i}+\varepsilon_{i}
$$

where, $E_{i}$ - is one of four dependent variables: (1) binary dummy variable indicating the exporter status, (2) ordinal variable describing the volume of exports, (3) intensity of export, measured as the logged share of exports in net sales, (4) log of exports. SEZ indicated the status of firms' operation in SEZs. $X_{i}$ was the vector of independent variables. Robust standard errors were used.

The type of the model was largely dependent on the nature of the dependent variable included. Therefore, in the case of export propensity, where the binary variable exp is used, a logit estimator was applied. With reference to the volume of exports, where the ordinal variable ex with nine strata is included, an ordered logistic regression model was estimated. As far as export intensity is considered, a tobit estimator on the logged share of exports in the net sales was applied. Due to the fact that variable lex_in cannot exceed 0 , it is treated as a censored variable. In the case of zero values, logs of 0.001 to the values of the original variable were added. Finally, an OLS estimator to the log of exports (lexports) is utilized.

The significant variables depicting the export performance were subsequently used in the second step of the research, in which a semi-observational experiment was carried out. The idea of incorporating a semiobservational experiment stemmed from the potential endogeneity problem that could arise, due to the motives driving firms' decisions to operate within special economic zones - e.g. firms can set up their business in SEZs because they intend to export.

With the common overlap assumption sustained (see Fig. 1), as well as the wellbalanced distributions of the explanatory variables used in order to calculate propensities 


\section{Fig. 1: The common support and common overlap test}

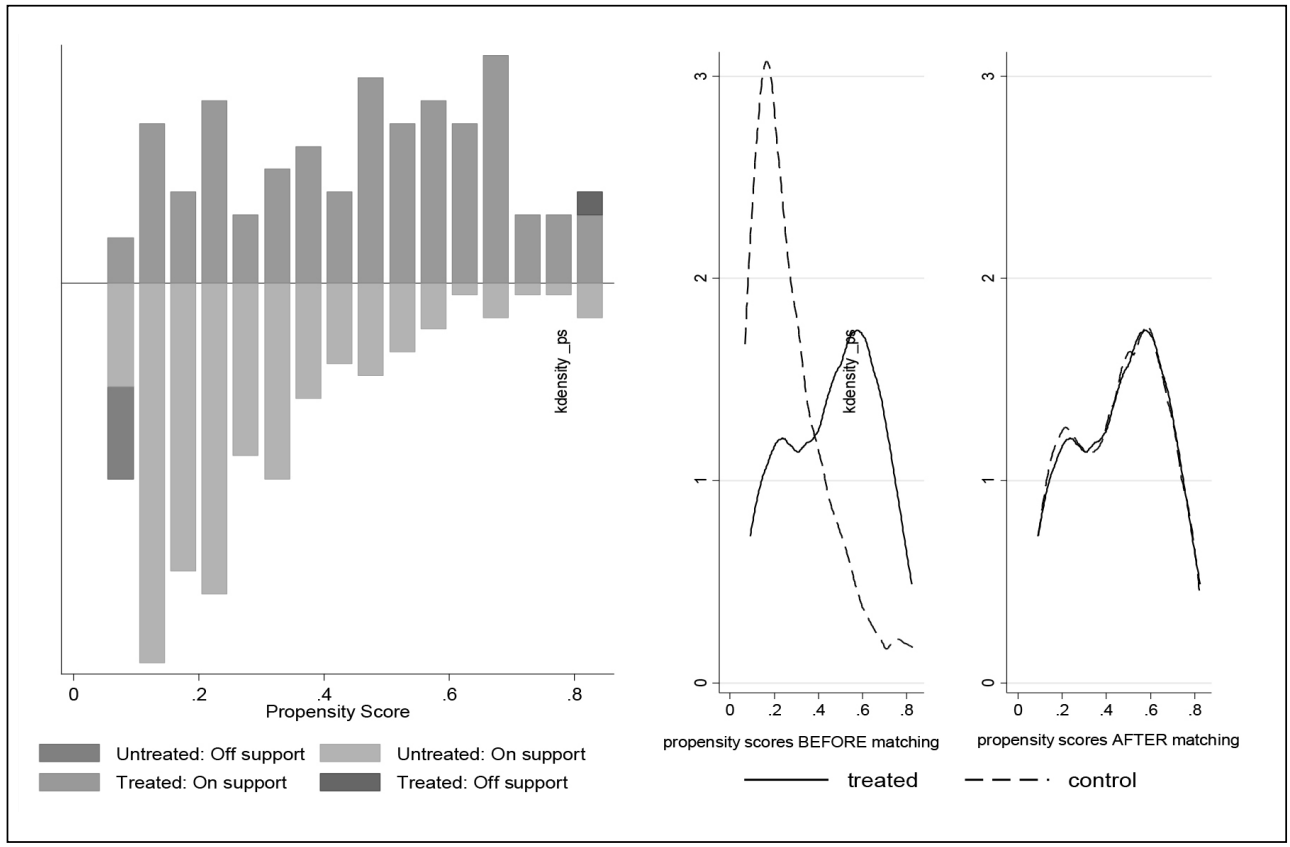

Source: own compilation

(discussed momentarily), the differences between SEZs and non-SEZs firms were tested with regard to their export performance.

Thanks to comparisons between weighted matched firms (having similar propensities scores and reflecting firms' characteristics) the authors could exclude the role of specific firms' characteristics in determining particular dependent variables and check whether the sole operation in SEZs significantly influenced firms' export activity (or have an insignificant effect based on the firms' characteristics). Thus, the application of a kernel-based propensity score matching estimator incorporated with a difference-in-difference strategy and calculation of the average treatment on the treated (ATT) has resulted in estimating the sole SEZs effect on firms, which had the following form (Guo \& Fraser, 2014):

$$
\begin{aligned}
& \operatorname{ATT}_{\text {Matching,DiD }}=\frac{1}{n_{1}} \sum_{i \in I_{1} \cap s_{p}}\left[\left(Y_{1 t i}-Y_{1 t^{\prime} i}\right)-\right. \\
& \left.-\sum_{j \in I_{0} \cap s_{p}} W(i, j)\left(Y_{0 t j}-Y_{0 t, j}\right)\right]
\end{aligned}
$$

where $I_{0}$ is a set of indices for controls, $I_{1}$ indicates the firms operating in SEZs (treated), $Y_{0}$ and $Y_{1}$ are the outcomes of the export performance variables for control firms and SEZ firms, respectively. The number of SEZs firms is represented by the term $\mathrm{n}_{1}$, while $t$ denotes a point in time after the treatment has taken place, whereas $t$ ' refers to a point in time prior to the treatment. Since the comparisons are made between the weighted average of the outcome variable for all of the control firms (from the common support region), represented by $\sum_{j \in I_{0} \cap s_{p}} W(i, j)$ with the outcome for the $i$ firm operating in SEZs (treated) in two different time periods (before and after treatment), one obtain a difference-in-difference estimator, similar to the one proposed by Heckman et al. (1997; 1998).

For each SEZ (treated) firm, the difference of the export performance variable $\left(Y_{1 t i}-Y_{1 t^{\prime} i}\right)$ is calculated and compared with the set of matches that have an average difference of $\sum_{j \in I_{0} \cap S_{p}} W(i, j) \quad\left(Y_{0 t j}-Y_{0 t^{\prime}}\right)$, depending on the closeness to the treated unit (based on 
the propensity score obtained from the logit equation estimation). Obviously, the closer the control group firm is to the $i$ SEZ (treated) firm, the higher the weight on propensity scores $W(i, j)$. Thus, the difference-in-difference estimate of the sample treatment effect for the treated firms is an average difference between the increment of the export performance variable for the $i$ SEZs firm and the weighted mean change in the outcome of the control group firms. The comparisons are only made on firms within the common support region, thus treated firms falling outside the region (with higher propensity score than the firms from the control group) are excluded from the analysis.

Due to the potential sensitivity of the results obtained in relation to the changes in the model specification, a series of tests were applied to validate if the average treatment effect on the treated (ATT) is stable, once one changes the bandwidth $(0.05,0.10 .2)$ and kernel type (Epanechnikov, Gaussian, biweight, uniform and tricube). Additionally, following Heckman et al. (1997), different trimming strategies as a second sensitivity test (1, 2, 5 percent) were applied in order to support the findings. The exclusion of spare cases (in the top and bottom percentiles) has enabled the verification if the obtained ATTs are sensitive to the distributional properties of the calculated propensity scores.

The validity of the obtained results was further verified using post-estimation tests, as proposed by Caliendo and Kopeinig (2008).
In the first step, the two sample t-tests between the mean values of the covariates in the group of SEZs and non-SEZs firms were checked before and after the kernel matching process. If there are no statistically significant differences between the treatment group (in this case SEZs firms) and the control group (non-SEZs firms) after the matching, then the latter is of good quality, as indicated in Tab. 2.

The second test involved the re-estimation of the logit models used in the process of calculation of the propensity scores (matched sample) and comparing the pseudo $\mathrm{R}^{2}$ before and after the treatment process has taken place. Low pseudo- $\mathrm{R}^{2}$ obtained after matching, indicates similar distributions of the covariates used in the estimation process among SEZs and non-SEZs firms and is a sign that the matching is of good quality.

\section{Results of Estimation and Discussion of Findings}

In this section the main outcomes of the analysis are presented. In the first step main differences among SEZ and non-SEZs firms are discussed. In the part 3.2 a series of regressions evaluating the role of SEZs on the firm-level export performance is presented, coupled with the set of sensitivity tests performed, validating susceptibility of the outcomes to the distributional properties of the data and the kernel type or the bandwidth selection.

Tab. 2: The covariate balance after the matching

\begin{tabular}{l|c|c|c|c|c} 
Weighted Variables & Mean Control & Mean Treated & Diff. & t & $\operatorname{Pr}(|\mathbf{T}|>|\mathbf{t}|)$ \\
\hline \multicolumn{5}{|c|}{ Covariates } \\
\hline Ilab_prod & 8.668 & 8.662 & -0.006 & 0.03 & 0.9778 \\
\hline lemp & 4.767 & 4.801 & 0.034 & 0.20 & 0.8424 \\
\hline imp & 0.769 & 0.775 & 0.006 & 0.12 & 0.9068 \\
\hline foe & 0.411 & 0.393 & -0.018 & 0.29 & 0.7731 \\
\hline \multicolumn{5}{|c|}{ Dependent variables } \\
\hline exp & 0.743 & 0.708 & -0.035 & 0.62 & 0.5341 \\
\hline ex & 2.864 & 2.843 & -0.021 & 0.07 & 0.9462 \\
\hline lex_in & -2.959 & -2.790 & 0.169 & 0.52 & 0.6025 \\
\hline lexports & 7.668 & 8.580 & 0.912 & 0.78 & 0.4384 \\
\hline
\end{tabular}

Source: own compilation

Note: balancing two sample t-tests in terms of the difference in the means of the weighted covariates between the control and treated groups in period $=0$. 
Tab. 3: Selected differences between SEZs and non-SEZs firms in 2007 and 2014

\begin{tabular}{|c|c|c|c|c|c|c|}
\hline Variable & $\begin{array}{c}\text { non-SEZs } \\
\text { (Mean) }\end{array}$ & $\begin{array}{c}\text { non-SEZs } \\
\text { (SD) }\end{array}$ & $\begin{array}{c}\text { SEZs } \\
\text { (Mean) }\end{array}$ & $\begin{array}{l}\text { SEZs } \\
\text { (SD) }\end{array}$ & T-stat & Difference \\
\hline ex & 1.20 & 1.80 & 3.01 & 2.73 & -9.94 & $1.81^{* \star *}$ \\
\hline $\exp$ & 0.44 & 0.50 & 0.73 & 0.44 & -7.59 & $0.29^{\star \star \star}$ \\
\hline foe & 0.13 & 0.34 & 0.38 & 0.49 & -7.49 & $0.25^{\star * *}$ \\
\hline im & 1.05 & 1.68 & 3.16 & 2.59 & -12.29 & $2.11^{* * *}$ \\
\hline imp & 0.42 & 0.49 & 0.78 & 0.41 & -9.72 & $0.36^{\star \star \star}$ \\
\hline lage & 2.73 & 0.55 & 2.64 & 0.51 & 2.01 & $-0.09^{*}$ \\
\hline lemp & 3.60 & 1.42 & 4.62 & 1.37 & -9.04 & $1.03^{\star \star \star}$ \\
\hline lex_in & -3.88 & 2.87 & -2.31 & 2.37 & -7.24 & $1.57^{\star \star \star}$ \\
\hline lexports & 3.51 & 9.88 & 9.96 & 8.64 & -7.74 & $6.45^{\star \star \star}$ \\
\hline limports & 2.31 & 9.58 & 7.71 & 9.55 & -4.37 & $5.40^{* * *}$ \\
\hline lim_in & -4.39 & 2.69 & -2.89 & 2.49 & -7.10 & $1.50^{\star \star \star}$ \\
\hline llab_prod & 7.80 & 1.64 & 9.02 & 1.66 & -8.29 & $1.22^{\star \star \star}$ \\
\hline Irenum & 6.72 & 1.52 & 8.22 & 1.65 & -9.35 & $1.49^{* \star *}$ \\
\hline Irenum_emp & 3.45 & 0.91 & 3.68 & 0.37 & -2.70 & $0.22^{* *}$ \\
\hline Itprod & 3.26 & 1.61 & 3.40 & 1.68 & -0.82 & 0.14 \\
\hline Iva & 8.00 & 1.66 & 9.42 & 1.71 & -8.31 & $1.42^{* \star *}$ \\
\hline Iva_cap & 1.00 & 1.67 & -0.38 & 1.11 & 9.19 & $-1.39^{\star * *}$ \\
\hline Iva_emp & 8.00 & 1.61 & 9.40 & 1.70 & -8.28 & $1.40^{* \star *}$ \\
\hline
\end{tabular}

Source: own calculations

Note: T-test statistics indicating the difference in the means between the two groups (SEZs vs. non-SEZs firms) are presented. ${ }^{* *} p<0.01,{ }^{* *} p<0.05,{ }^{*} p<0.1$. Variables starting with the letter I are in logs.

\subsection{Main Differences between SEZ and Non-SEZ Firms in Terms of Export Behaviour}

There is a detailed description of the differences between SEZs and non-SEZs presented in Tab. 3. As one can see, for the majority of the variables included, the differences are statistically significant, with $p<0.01$. An immense difference can be seen as regards log of exports (lexports), log of imports (limports), the scale of exports (ex), log exports and imports share in total sales (lex_in and lex_in - respectively). This reveals that operating in SEZs (ceteris paribus) influences the intensive margin of exports and the exports intensity. The SEZs influence on the extensive margin of exports is not statistically important.

Large differences are also observed regarding log remuneration (Irenum), log labour productivity (llab_prod), log value added (Iva), log value added per employee (Iva_emp), and log capital productivity (Iva_cap), which are higher for entities in SEZs. However, in the case of the value added per employee (Iva_emp), the difference is smaller, albeit still statistically significant. In the case of value added per unit of capital (fixed assets - Iva_cap), the situation is reversed: productivity is higher for entities in non-SEZs. It may be due to the fact that in many cases, the economic activity located in SEZs is capital intensive. Minor differences may be observed when the log age (lage) of the firms is analysed. Similarly, firms operating in SEZs are slightly younger (9 percent on the average).

Having said that, for most of the variables included in the econometric modelling, one can see statistically significant differences between entities in SEZs vs. non-SEZs - it is therefore more convenient to indicate the variables, for which the differences are insignificant. 
The only one is the log of total productivity (Itprod), calculated as the geometric mean between the labour productivity and the capital productivity (on the basis of the value added) see Brodzicki and Ciołek (2016) for details.

\subsection{The Role of SEZs in Firm-Level Export Performance}

In Tab. 4, four different aspects associated with exporting behaviour are analysed. In the first column, the probability of undertaking the export activity is presented. In fact, it relates to the extensive export margin (number of exporting firms). A logit estimator equal to 1 is used, if the exporting activity is carried out by an entity, and 0 if there are no exports. The second column depicts the scale of exports as an ordinal variable with 9 strata. Column 3 shows the estimation of the export intensity (log share of exports in total sales), based on the tobit estimator technique. Finally, the focus is concentrated on the log of exports (column 4) that relates to the export intensive margins (exports per firm). Many other estimations were carried out with different sets of variables - may be delivered upon request.

Labour productivity has a positive, statistically significant influence on the exporter status and on a scale of exports. This is in line with our expectations, as the firms' heterogeneity concept says that only the most productive business entities can become exporters. There is a certain productivity threshold that must be reached in order to facilitate exports. Higher labour productivity also translates into the scale of exports, meaning that a firm "moves" to higher export strata. As regards the log of exports (column 4), no statistically significant influence of the labour productivity has been identified. Our results can be interpreted as follows: labour productivity positively influences the extensive margin of exports and has no significant effect on the intensive margin. However, further analysis is recommended, if better, more comprehensive information on the value of exports becomes available. On the other hand, labour productivity influences export intensity in a statistically significant negative way, the coefficient of influence being close to zero. This may reflect several factors: (a) although firms are/become exporters, they focus their economic activity on Poland's market, (b) the primary reason for doing so is the avoidance of risk associated with foreign expansion, (c) Poland itself offers a large domestic market (home market effect matters), in which high labour productivity also is important and "pays off".

The level of employment, which is a proxy of a firm's size, positively influences all four dependent variables, with the lowest variable $p<0.1$ being recorded in the case of the probability of exporting. This is in line with our expectations, stemming from the empirical research within the heterogeneity concepts: exporters are rather big firms (it reflects economies of scale). In bigger firms, the sales departments are usually more diversified, with parts of the sales personnel being delegated to servicing the foreign markets only.

In the case of the four model estimations presented in the table, being an importer has a positive, statistically significant influence on exports. It reflects the "learning by importing" effect described in the literature. The fact is that in most cases importing is an initial stage to exporting (reflecting learning by means of the importing effect).

The presence of foreign capital increases the probability that a firm is an exporter. It also positively and significantly influences the scale of exports and export intensity. It means that although many of the FOEs in Poland are focused on Poland's market, being (often) a part of bigger, multinational structures, this increases (albeit the coefficient of influence is relatively low) the intensity of exports. As regards the consequences of being localised within a SEZ, this fact does not significantly influence the probability of becoming an exporter, or the scale of exports.

Summing up, as regards the research question formulated, our estimations (Tab. 4) show the moderate influence of the SEZ on exports. Labour productivity and foreign capital presence capture most of the positive influence exerted on different aspects of exporting.

However, the results could have been biased, because of the problem of endogeneity, potentially distorting the results. To reduce the endogeneity bias, a semi-observational experiment is conducted in which the role of firms' characteristics on export performance is excluded. The sole effect of functioning in SEZs on firms is calculated, by comparing the output of SEZs firms (treated) with the weighted (depending on their propensity scores) output of non-SEZs firms (control). 


\section{Tab. 4: Probability of exporting, scale of exports and export intensity}

\begin{tabular}{|c|c|c|c|c|}
\hline & (1) & (2) & (3) & (4) \\
\hline Variables & Exporter status & Scale of exports & Export intensity & Log exports \\
\hline \multirow[t]{2}{*}{ llab_prod } & $1.429^{* * *}$ & $1.925^{* * *}$ & $-0.251^{* * *}$ & -0.113 \\
\hline & $(0.086)$ & $(0.081)$ & $(0.068)$ & $(0.213)$ \\
\hline \multirow[t]{2}{*}{ lemp } & $1.180^{*}$ & $1.544^{* * *}$ & $0.840^{* * *}$ & $3.062^{* * *}$ \\
\hline & $(0.099)$ & $(0.083)$ & $(0.074)$ & $(0.253)$ \\
\hline \multirow[t]{2}{*}{ imp } & $8.865^{\star \star *}$ & $5.950^{* * *}$ & $1.354^{* * *}$ & $4.614^{* \star *}$ \\
\hline & $(0.258)$ & $(0.258)$ & $(0.274)$ & $(0.949)$ \\
\hline \multirow[t]{2}{*}{ foe } & $2.533^{* * *}$ & $2.944^{* * *}$ & $0.527^{* *}$ & 1.083 \\
\hline & $(0.328)$ & $(0.205)$ & $(0.265)$ & $(0.892)$ \\
\hline \multirow[t]{2}{*}{ sez } & 1.124 & 1.200 & $0.437^{*}$ & $1.740^{* *}$ \\
\hline & $(0.269)$ & $(0.186)$ & $(0.233)$ & $(0.790)$ \\
\hline Observations & 518 & 518 & 518 & 518 \\
\hline Pseudo $\mathrm{R}^{2}$ & 0.357 & 0.237 & 0.0794 & \\
\hline $\mathrm{R}^{2}$ adj. & & & & 0.389 \\
\hline Log-Lik & -224.6 & -718.3 & $-1,166$ & $-1,791$ \\
\hline LR Chi & 167.7 & 231.2 & & \\
\hline $\mathrm{F}$ & & & 70.76 & 107.8 \\
\hline$p$ & 0.000 & 0.000 & 0.000 & 0.000 \\
\hline AIC & 461.1 & 1,463 & 2,347 & 3,593 \\
\hline $\mathrm{BIC}$ & 486.6 & 1,518 & 2,377 & 3,619 \\
\hline
\end{tabular}

Source: own compilation

Note: Pooled data for 2007 and 2014. Robust standard errors in parenthesis. For columns 1 and 2 the odds ratios are presented instead of coefficients. ${ }^{* * *} p<0.01,{ }^{* *} p<0.05,{ }^{*} p<0.1$.

Tab. 5 depicts the results of the comparison of firms in SEZs and outside SEZs following the kernel-based matching. It means that the probability of treatment (here operation in SEZs) is controlled for the log of employment and labour productivity, presence of foreign capital, the size of the firm (log of employment), as well as importer status. The calculated average treatment of the treated (ATT) indicates the difference in the export performance between 2007 and 2014, with the exclusion of selected firms' characteristics (Tab. 2, top variables). By doing so, we could capture the real effect of operation in SEZs on export propensity, scale of exports, exports intensity and volume of exports.
The differences between SEZs and nonSEZs in years 2007-2014 were significant, as proved by the level of significance for the average treatment effect on the treated (ATT) on the matched sample. SEZs firms had a higher increase in: export propensity (ATT $=0.184)$, export intensity $($ ATT $=1.179)$ and scale of exports (ATT $=1.134$ ), as compared to the control sample. The highest differences were observed in relation to the increase in the log of exports (ATT $=3.173$ ), which tripled in comparison to the control firms.

The sensitivity test performed in order to verify the validity of the obtained results presented in Tab. 2 supports the quality of the covariates' balance between SEZs and a nonSEZs group of firms. The two sample t-tests 


\section{Ekonomie}

Tab. 5: The effects of firm location in SEZs on their export performance for 2007-2014

\begin{tabular}{l|c|c|c|c}
\multicolumn{1}{c|}{ Column } & $(\mathbf{1})$ & $\mathbf{( 2 )}$ & $\mathbf{( 3 )}$ & $\mathbf{( 4 )}$ \\
\hline \multicolumn{1}{c|}{ Variables } & Exporter status & Scale of exports & Export intensity & Log exports \\
\hline ATT & $0.184^{* * *}$ & $1.134^{* *}$ & $1.179^{*}$ & $3.173^{* *}$ \\
\hline & $(0.0591)$ & $(0.430)$ & $(0.577)$ & $(1.200)$ \\
\hline Observations & 518 & 518 & 518 & 468 \\
\hline R-squared & 0.013 & 0.021 & 0.023 & 0.029 \\
\hline Mean control $\mathrm{t}(0)$ & 0.743 & 2.864 & 0.259 & 7.668 \\
\hline Mean treated $\mathrm{t}(0)$ & 0.708 & 2.843 & 0.677 & 8.580 \\
\hline Diff $\mathrm{t}(0)$ & -0.0347 & -0.0215 & 0.418 & 0.912 \\
\hline Mean control $\mathrm{t}(1)$ & 0.631 & 2.294 & 0.191 & 7.162 \\
\hline Mean treated $\mathrm{t}(1)$ & 0.780 & 3.407 & 1.787 & 11.250 \\
\hline Diff $\mathrm{t}(1)$ & 0.149 & 1.113 & 1.597 & 4.084 \\
\hline
\end{tabular}

Source: own compilation

Note: constant variables are not presented. Robust standard errors in parenthesis. ${ }^{* *} p<0.01,{ }^{* *} p<0.05,{ }^{*} p<0.1$. $\mathrm{t}(0) 2007, \mathrm{t}(1) 2014$.

Tab. 6: The sensitivity of ATTs with respect to the kernel type and bandwidth

\begin{tabular}{|c|c|c|c|c|c|}
\hline Column & & (1) & (2) & (3) & (4) \\
\hline Bandwidth & Kernel type & $\begin{array}{l}\text { Exporter } \\
\text { status }\end{array}$ & $\begin{array}{c}\text { Scale } \\
\text { of exports }\end{array}$ & $\begin{array}{l}\text { Export } \\
\text { intensity }\end{array}$ & Log exports \\
\hline \multirow[t]{2}{*}{0.05} & Epanechnikov & $0.184^{* * *}$ & $1.134^{* *}$ & $1.179^{*}$ & $3.173^{\star *}$ \\
\hline & & $(0.0591)$ & $(0.430)$ & $(0.577)$ & $(1.200)$ \\
\hline \multirow[t]{2}{*}{0.1} & Epanechnikov & $0.168^{* *}$ & $1.050^{* *}$ & $1.135^{\star}$ & $3.123^{\star *}$ \\
\hline & & $(0.0574)$ & $(0.407)$ & $(0.561)$ & $(1.168)$ \\
\hline \multirow[t]{2}{*}{0.2} & Epanechnikov & $0.159^{* *}$ & $0.985^{\star *}$ & $1.107^{*}$ & $3.045^{\star *}$ \\
\hline & & $(0.0551)$ & $(0.364)$ & $(0.556)$ & $(1.139)$ \\
\hline \multirow[t]{2}{*}{0.05} & Gaussian & $0.170^{\star * *}$ & $1.060^{* *}$ & $1.159^{*}$ & $3.166^{\star *}$ \\
\hline & & $(0.0575)$ & $(0.404)$ & $(0.561)$ & (1.164) \\
\hline \multirow[t]{2}{*}{0.05} & Biweight & $0.184^{\star \star \star}$ & $1.116^{\star \star}$ & $1.137^{*}$ & $3.038^{\star *}$ \\
\hline & & $(0.0598)$ & $(0.425)$ & $(0.571)$ & $(1.182)$ \\
\hline \multirow[t]{2}{*}{0.05} & Uniform & $0.179^{* * *}$ & $1.176^{* *}$ & $1.227^{*}$ & $3.349^{* *}$ \\
\hline & & $(0.0596)$ & $(0.456)$ & $(0.586)$ & $(1.234)$ \\
\hline \multirow[t]{2}{*}{0.05} & Tricube & $0.182^{\star * *}$ & $1.163^{* *}$ & $1.208^{*}$ & $3.287^{* *}$ \\
\hline & & $(0.0590)$ & $(0.443)$ & $(0.587)$ & $(1.228)$ \\
\hline
\end{tabular}

Source: own compilation Note: constant variables are not presented. Robust standard errors in parenthesis. ${ }^{* *} p<0.01,{ }^{* *} p<0.05,{ }^{*} p<0.1$. 
indicated insignificant differences among a treated and non-treated group of firms in the matched sample. Similarly, relative low pseudo- $R^{2}$ (from 0.013 to 0.029 ) on the matched sample (Tab. 5), supported the aforementioned results indicating similar distributions of the covariates between the two groups of firms in the matched sample.

In order to eliminate the sensitivity of the method selection on the results, several additional tests were conducted in order to validate the obtained findings. In Tab. 6 , the effects of different specifications applied in the semi-observational experiment are presented with respect to the bandwidth and the kernel function used, while maintaining the number of observations in the dataset constant. The significance of the results is sustained, resulting only in minor differences in the calculated ATTs, depending on the criteria used, which in general tend to support the prior findings.

The application of the trimming strategy (reducing the number of observations in different percentiles from the upper and lower end of the distribution) with the default bandwidth (0.05) and kernel function (Epanechnikov) sustained, acknowledge the obtained ATTs in the case of exporter status (Tab. 7). However, the treatment effects concerning the scale of exports, export intensity and the log of exports were sensitive to the distributional properties of the propensity scores included in the dataset. Hence, the reduction in the number of observations (from 1 to 5 percent) has affected the significance of the obtained results in this regard, changing the calculated average treatment effect on the export intensity in a significant manner.
One should notice a relatively small number of observations in the dataset, further reduced by the few missing data on firms' financial standings, what could constitute one of the causes of such sensitivity. The other is the uneven distribution of the pscores within each of the firm groups, resulting in sparse values from the mean. In the latter case, the treatment estimator is not efficient. Therefore, one cannot fully acknowledge the positive role of SEZs on the scale of exports, export intensity and log exports that were indicated in Tab. 5. However, having access to a bigger dataset, could have resulted in more robust findings.

The significant differences, controlling for firms' characteristics imply the source of observed dissimilarities in the firm-level behaviour concerning export performance. Thus, the observed differences in firms' export performance, stemmed mostly from their firmlevel characteristics (firm heterogeneity) and narrowly from the operation in SEZs, which had a substantial effect only on firms' export propensity (exporter status). The findings are in line with the foundations of the heterogeneity concept, following the post-Melitz approach in the recent analysis of the international trade and indicate the need for incorporating new variables describing firm-heterogeneity, namely the operation in the privileged areas or regional aid beneficiaries.

\section{Summary and Implications for the Economic Policy}

Special economic zones play an important role in the global economy and in the economies of particular countries, including Poland.

Tab. 7: The sensitivity of ATTs with respect to the trimming strategy

\begin{tabular}{c|c|c|c|c} 
Column & $\mathbf{( 1 )}$ & $\mathbf{( 2 )}$ & $\mathbf{( 3 )}$ & $\mathbf{( 4 )}$ \\
\hline Trim & Exporter status & Scale of exports & Export intensity & Log exports \\
\hline $1 \%$ & $0.188^{* *}$ & $1.193^{*}$ & 0.633 & 3.150 \\
\hline & $(0.0926)$ & $(0.610)$ & $(0.587)$ & $(2.308)$ \\
\hline $2 \%$ & $0.181^{* *}$ & $1.104^{*}$ & 0.534 & 2.832 \\
\hline & $(0.0910)$ & $(0.617)$ & $(0.582)$ & $(2.286)$ \\
\hline $5 \%$ & $0.179^{*}$ & 0.721 & 0.548 & 2.753 \\
\hline & $(0.0969)$ & $(0.596)$ & $(0.600)$ & $(2.345)$ \\
\hline
\end{tabular}


Their significant impact is especially expected in terms of the contribution to exports. This expectation is highly linked to one of the aims of the SEZs establishment, which is clearly the enhancement of exports. Given the whole body of literature, addressing the SEZs-led export activity, the vast majority of papers investigate only their impact on the national economy, restricting the research methods used to the descriptive analyses or case studies of the specific zones. The existing empirical evidence (econometric one) in the vast majority of papers regarding zonal operation does not account for the endogeneity bias, which can have a distorting effect on the results. Nevertheless, little is known about the real (based on solid evidence) SEZs' influence on the firm-level characteristics, with regard to the creation of exports. Therefore, in this paper the method of SEZs evaluation incorporating for endogeneity bias elimination was proposed and a semi-observational experiment was run, which enabled the examination of the firm-level consequences of SEZs operation.

In the research, the influence of labour productivity on exports was verified. The conclusions are in line with the heterogeneity concept, assuming that higher productivity increases the probability of exporting. The findings also depict the role of the motives that drive the business activity; for many firms, the Polish market is the one to focus on. However, firms with foreign capital reveal an increased export intensity (measured as exports share in total sales). In bigger firms, a higher scale of exports, as well as exports intensity is observed. The strongest and most significant influence on exports is exerted by the fact that a firm is engaged in importing activity, and benefits from foreign investor participation.

The findings are important for policymakers in Poland in relation to the further SEZs operation, as well as the directions which the zone-led programmes should follow, and show the role of the motives/strategies endorsed by the firms located in SEZs. According to the unpresented outcomes of the conducted survey, firms locating in SEZs were especially interested in: obtaining tax privileges (from SEZs and local authorities as well), low utility costs, access to cheap resources, benefits from concentration of firms, operating within the same industry and the relative ease of technology spill-over diffusion. These beliefs, stressed the role of efficiency seeking motives, together with resource-seeking, being in the central focus of investors functioning within the zones.

The results also reveal how zonal operation may affect firms in other countries, adopting similar SEZs-led programmes, knowing the potential differences in the economy structure, sectoral composition of the inflowing capital or differences in the SEZs programmes. The research has shown that the SEZs programme has failed to achieve some of its main goals.

Being inspired by Mayer and Ottaviano (2007) the authors examined the pattern of internationalisation on the basis of exports and the role assumed by SEZs in relation thereto. The SEZs' influence on export performance occurs on the basis of the intensive margin, not rather than on the basis of an extensive one. It means that the SEZ do not increase the number of exporters. Thus, their functioning does not increase the number of "exclusive club" members. It occurs rather via productivity increases or foreign capital involvement. From the point of view of the effectiveness of exports promotion, the overall investment climate shall be improved (not only in SEZs); the increases in labour productivity shall result in the increased number of exporters (extensive margin of trade). Furthermore, the attraction of direct foreign investment is a way to stimulate exports. These arguments shall be taken into account in the evaluation of costs and benefits associated with the functioning of SEZs. As Mayer and Ottaviano (2007) stipulate, an extensive margin is the most desired one (exporting firms are bigger, more productive, etc.). The SEZ functioning, as already mentioned, does not positively contribute to this margin.

The application of the kernel-based propensity score matching the difference-indifference approach has enabled the elimination of potential endogeneity bias, that could arise during the analysis. The calculated ATTs (the sole effect of zonal operation on firms) brought us to the conclusion that SEZs had positive effects on firms': export propensity, scale of exports, export intensity, log exports. However, most of the ATTs were not robust to all of the tests performed. Only in the case of export propensity, the positive role of SEZs on firms' performance could be fully acknowledged.

The research done in the paper is based on the unique firm-level data for Poland. However, 
to the belief of the authors, the results are more universal. They are an important contribution to the discussion about SEZs performance as well as the role played by foreign direct investors. Poland is competing with other countries of the region, inc. the Czech Republic for FDI. The "beauty contest" also embraces the scale and character of incentive packages granted in SEZs. The research sheds light on aspects of SEZs operations that constitutes an important information package for FDls (when they for instance negotiate investment conditions and incentive packages), for SEZs (when they select investors) and for the national authorities (when they negotiate with the European Commission the rules on which public aid in SEZs can be granted).

The results, due to the two estimation procedures used (without and with correction for endogeneity bias) do not empower to formulate unequivocal, robust conclusions about SEZs influence on the other aspects of export performance (scale of exports, export intensity, export volume). The findings were run on a relatively small population of SEZs and non-SEZs firms. The statistical procedure was maintained sound. However the estimation on the bigger dataset could be to some extent beneficial, but would limit the number of the dependent variables tested, due to the data concerns described in section 2 .

However, one should remember that the impact of the SEZs on the national economy is broader in its nature, and comprises for example the employment/investment/foreign trade contribution, as well as increases the total investment attractiveness of the country or potential spill-over effects generated by the FOEs located within the zones. Therefore, the overall impact of the SEZs is still a matter of concern and an interesting issue for a policy debate, which should be further investigated. This interest is sustained due to the potential and in many cases unexpected negative effects of the zones operation (e.g. market failure, crowding-out), coupled with the costs associated with the establishment of zonal programmes and the upkeep thereof. Therefore, the privileged areas in Europe are under the supervision of the European Commission, national institutions, researchers and policymakers.

Acknowledgements: The paper was elaborated within the research project entitled
'Foreign Trade in Special Economic Zones in Poland', financed by the National Science Center (Poland) within the grant decision no. DEC2013/11/D/HS4/04007. We would like to thank Tomasz Brodzicki (University of Gdańsk, Poland) for the helpful comments to the first version of the paper. The usual disclaimer applies.

\section{References}

Aggarwal, A. (2004). Export processing zones in India: analysis of the export performance (ICRIER No. 148). New Delhi.

Aggarwal, A. (2005). Performance of export processing zones: a comparative analysis of India, Sri Lanka and Bangladesh. Indian Council for Research on International Economic Relations, 155, 10-13.

Aggarwal, A. (2012a). SEZ-led Growth in Taiwan, Korea, and India: Implementing a Successful Strategy. Asian Survey, 52(5), 872-899. https://dx.doi.org/10.1525/ as.2012.52.5.872.

Aggarwal, A. (2012b). Social and economic impact of SEZs in India. New Delhi: Oxford University Press.

Amirahmadi, H., \& Wu, W. (1995). Export Processing Zones in Asia. Asian Survey, 35(9), 828-849. https://dx.doi.org/10.2307/2645785.

Antràs, P., \& Yeaple, S. R. (2014). Multinational Firms and the Structure of International Trade. In G. Gopinath, E. Helpman, \& K. Rogoff (Eds.), Handbook of international economics (Vol. 4). Elsevier.

Bräutigam, D., \& Xiaoyang, T. (2011). African Shenzhen: China's special economic zones in Africa. The Journal of Modern African Studies, 49(01), 27-54. https://dx.doi. org/10.1017/S0022278X10000649.

Brodzicki, T., \& Ciołek, D. (2016). Determinanty działalności eksportowej polskich firm produkcyjnych. Gospodarka Narodowa. (2), 59-76.

Caliendo, M., \& Kopeinig, S. (2008). Some Practical Guidance for the Implementation of Propensity Score Matching. Journal of Economic Surveys, 22(1), 31-72. https://dx.doi. org/10.1111/j.1467-6419.2007.00527.x.

Chaudhuri, S., \& Yabuuchi, S. (2010). Formation of special economic zone, liberalized FDI policy and agricultural productivity. International Review of Economics \& Finance, 19(4), 779-788. https://dx.doi.org/10.1016/j. iref.2010.02.004. 
Damborský, M., Wokoun, R., \& Krejčová, N. (2013). The effectiveness of industrial zones support in the Czech republic. E\&M Ekonomie a Management, 16(4), 104-117.

Dobronogov, A., \& Farole, T. (2012). An Economic Integration Zone for the East African Community: Exploiting Regional Potential and Addressing Commitment Challenges [Policy Research working paper no. WPS 5967]. Washington, DC: World Bank.

Farole, T. (2011). Special economic zones in Africa: Comparing performance and learning from global experiences. Directions in development. Trade. Washington, DC: World Bank. https://doi.org/10.1596/978-0-8213-8638-5.

Farole, T., \& Akinci, G. (2011). Special economic zones: Progress, emerging challenges, and future directions. Washington, DC: World Bank.

FIAS. (2008). Special Economic Zones: Performance, Lessons Learned, and Implications for Zone Development. Washington, DC.

Forsgren, M. (2008). Theories of the multinational firm: A multidimensional creature in the global economy. Cheltenham, Glos, UK, Northampton, MA: Edward Elgar.

Ge, W. (1999). Special Economic Zones and the Opening of the Chinese Economy: Some Lessons for Economic Liberalization. World Development, 27(7), 1267-1285. https:// dx.doi.org/10.1016/S0305-750X(99)00056-X.

Gopinath, G., Helpman, E., \& Rogoff, K. (Eds.). (2014). Handbook of international economics (Vol. 4). Elsevier.

Guo, S., \& Fraser, M. W. (2014). Propensity score analysis: Statistical methods and applications (Vol. 11). Thousand Oaks, CA: SAGE Publications.

Heckman, J. J., Ichimura, H., \& Todd, P. E. (1997). Matching As An Econometric Evaluation Estimator: Evidence from Evaluating a Job Training Programme. The Review of Economic Studies, 64(4), 605-654. https://dx.doi. org/10.2307/2971733.

Heckman, J. J., Ichimura, H., \& Todd, P. (1998). Matching as an econometric evaluation estimator. The Review of Economic Studies, 65(2), 261-294. https://dx.doi. org/10.2307/2971733.

Johansson, H., \& Nilsson, L. (1997). Export processing zones as catalysts. World Development, 25(12), 2115-2128. https:// dx.doi.org/10.1016/S0305-750X(97)00103-4.

Kumar, R. (1989). India's export processing zones. Oxford University Press.
Kundra, A. (2000). The Performance of India's Export Zones: A Comparison with the Chinese Approach. New Delhi: SAGE Publications Pvt. Limited.

Lonarkar, P. P. (2014). Export Performance Analysis of India's SEZ. Journal of International Economics, 5(1), 18-30.

Mayer, T., \& Ottaviano, G. I. P. (2007). The happy few: The internationalisation of European firms; new facts based on firm-level evidence. Bruegel blueprint: Vol. 3. Brussels.

McIntyre, J. R., Narula, R., \& Trevino, L. J. (1996). The role of export processing zones for host countries and multinationals: a mutually beneficial relationship? The International Trade Journal, 10(4), 435-466. https://dx.doi. org/10.1080/08853909608523864.

Milberg, W., \& Amengual, M. (2008). Economic development and working conditions in export processing zones: A survey of trends. Geneva: International Labour Office.

Moberg, L. (2015). The political economy of special economic zones. Journal of Institutional Economics, 11(1), 167-190. https://dx.doi. org/10.1017/S1744137414000241.

Neumark, D., \& Simpson, H. (2015). Place-Based Policies. In G. Duranton, J. V. Henderson, \& W. C. Strange (Eds.), Handbook of regional and urban economics (Vol. 5, pp. 1197-1287). Amsterdam, The Netherlands: North Holland. https://dx.doi.org/10.1016/B9780-444-59531-7.00018-1.

Pradhan, J. P., \& Zohair, M. (2014). Subnational Export Performance and Determinants: Evidence from Two Indian States (No. MPRA Paper No. 60029). Retrieved from Munich Personal RePEc Archive website: https://mpra.ub.uni-muenchen.de/60029/.

Siroën, J.-M., \& Yücer, A. (2014). Trade performance of free trade zones (Document de travail / UMR DIAL 225). Paris.

Tantri, M. L. (2011). Trade Performance of SEZs in India: A Disaggregated-level Analysis. Margin: The Journal of Applied Economic Research, 5(2), 267-288. https://dx.doi. org/10.1177/097380101100500205.

Tantri, M. L. (2012). Effectiveness of the Special Economic Zone Policy over the Export Processing Zone Structure in India: Trade Performance at the Aggregate level. Journal of Asian Public Policy, 5(1), 23-40. https://dx.doi. org/10.1080/17516234.2012.661948.

Wang, J. (2013). The economic impact of special economic zones: Evidence from 
Chinese municipalities. Journal of Development Economics, 101, 133-147. https://dx.doi. org/10.1016/j.jdeveco.2012.10.009.

Wong, K.-Y., \& Chu, D. K. Y. (1984). Export Processing Zones and Special Economic Zones as Generators of Economic Development: The Asian Experience. Geografiska Annaler. Series B, Human Geography, 66(1), 1-16. https://dx.doi.org/10.2307/490524.

Zeng, D. Z. (2010). Building engines for growth and competitiveness in China: Experience with special economic zones and industrial clusters. Washington, D.C.: World Bank Publications.

Zeng, D. Z. (2011). How do special economic zones and industrial clusters drive China's rapid development? [Policy Research Working Paper No. 5583].
Zeng, D. Z. (2014). China and Africa's Experiences with Special Economic Zones: What Can We Learn? [Working Paper Series No. E.2014004]. China Center for Economic Research.

Jarosław Michał Nazarczuk, Ph.D. University of Warmia and Mazury in Olsztyn Faculty of Economic Sciences Poland jaroslaw.nazarczuk@uwm.edu.pl

Assoc. Prof. Stanisław Umiński, Ph.D. University of Gdańsk Faculty of Economics Poland uminski@univ.gda.pl 


\title{
Abstract
}

\section{THE IMPACT OF SPECIAL ECONOMIC ZONES ON EXPORT BEHAVIOUR. EVIDENCE FROM POLISH FIRM-LEVEL DATA}

\author{
Jarosław Michał Nazarczuk, Stanisław Umiński
}

Special economic zones play an important role in the global economy and in the economies of particular countries, including Poland. Given the whole body of literature on SEZs-led export activity, the vast majority of papers, restrict the research methods used to the descriptive analyses or the case studies of specific zones, only describing the impact thereof on the national economy. The existing empirical evidence (econometric) in the vast majority of papers associated to zonal operation does not account for the endogeneity bias, which can have a distorting effect on the results. Nevertheless, little is known about the real (based on solid evidence) SEZ influence on the firm-level characteristics, with regard to the creation of exports.

The role of SEZs in relation to firm-level export probability/scale/intensity/volume has been investigated using a unique dataset for 155 firms operating in special economic zones (SEZs) in Poland, accompanied by the data for 155 non-SEZs economic entities (matched sample). With the use of different estimation techniques, conditioned by the uneven nature of the tested dependent variables, a positive role of SEZs was found in relation to certain aspects of the firm-level exports. The possible endogeneity problem in the SEZ variable was properly addressed by utilising a kernelbased propensity score matching difference-in-difference estimator and by calculating the average treatment effect on the treated (ATT), accompanied by a series of robustness/sensitivity tests (changes in kernel type, bandwidth, dataset trimming).

The results provide consistent evidence on the effect of the SEZs on export probability in firms operating within the zones, as compared to the control group. The positive impact of the SEZs on the scale of exports, export intensity and the volume of exports was however sensitive to dataset trimming. Hence, the impact of the SEZs operation in this regard could not be full acknowledged.

Key Words: Special Economic Zones, exports, Poland, treatment effects, counterfactual analysis, firm heterogeneity.

JEL Classification: F14, D22, H25.

DOI: 10.15240/tul/001/2018-3-001 